\title{
Virtual Field Trips: Bringing College Students and Policymakers Together through Interactive Technology
}

\author{
Janet M. Box-Steffensmeier, Ohio State University \\ J. Tobin Grant, Ohio State University \\ Scott R. Meinke, Ohio State University \\ Andrew R. Tomlinson, Ohio State University
}

In a democratic society, education in the values and operation of the political system takes on a high level of importance. Citizens must be made conscious of the system within which policy is created and, as instructors at the college level, we face the task of presenting students with facts, theories, and opinions about government. Although instructors can introduce students to important ideas through lectures, readings, and discussions, many students best learn political concepts when given opportunities to apply those ideas in the context of the real world of politics. For these students, a particularly effective political science course is one that allows them to interact with political professionals so that the students can explore the meaning of the subject matter first-hand. Although this type of course is rare among the offerings of political science departments, the information that students glean from this sort of interaction can increase their knowledge of how the political system works and give them the understanding they need to actively engage the political process.
In some undergraduate legislative politics and policy-making courses, students benefit from open discussions with their member of Congress during class time. However, because of the conflicting schedules of when the class meets and when the member is available in the district (typically not during the week), congressional staffers, who can discuss only their impressions of what the member may think, often appear in lieu of the actual member. Meanwhile, meeting with federal bureaucrats, legislative committee staffers, and others working "inside the beltway" is usually impossible. Our educational institutions recognize this and many have established programs through which students can visit Washington and observe the policy process firsthand. Unfortunately, thousands of eager students would like to travel and study in Washington, DC, but lack the opportunity or resources to do so.

Interactive technology, especially the Internet and interactive video conferencing, has the potential to overcome the constraints of time, distance, and funding that too often
Janet M. Box-Steffensmeier is an associate professor at Ohio State University. She received honorable mention for the Rowman \& Littlefield Award for Innovative Teaching in Political Science (with John Freeman, University of Minnesota) for an interactive video course in methodology in 1997. Her research interests include American politics and methodology.

J. Tobin Grant is a Ph.D. candidate in political science at Ohio State University. His interests include legislative politics, political behavior, and political methodology. His dissertation is on the timing of legislative decisions in the U.S. Congress. His undergraduate degree is from Wheaton College.
Scott R. Meinke is a Ph.D. candidate in political science at Ohio State University. His research interests include legislative politics, urban politics, and the American presidency, and his dissertation explores long-term position change in House floor voting. His undergraduate degree is from Wittenberg University.

Andrew R. Tomlinson is a Ph.D. candidate in political science at Ohio State University. His interests include voting behavior, public opinion, and political methodology, and his dissertation is on strategic voting in the United States. His undergradvate degree is from the College of William \& Mary. restrict students' access to public policymakers. Students seeking information about politics and policy making can visit websites for politicians, consultants, and bureaucratic offices, which offer varying amounts of information about each participant's role in the political process (Crawford 1998). In a much more direct and immediate way, video conferencing can foster interaction between Washington policymakers and students thousands of miles away.

We took advantage of this technology in a course titled Congress and the Policy Process. The coursewhich included traditional lectures, computer labs, use of the Internet, and video conferencing-was designed with two objectives beyond learning the basic material. First, we wanted the students to experience politics in an engaging way through real-time discussions with policymakers. Second, we wanted students to become adept users of a variety of technological mechanisms, including electronic political databases. In the interest of achieving this last objective, we required students to undertake guided empirical research using the Congressional Database

(Frantzich 1995) in the computer lab once a week during the quarter. Overall, we found the use of interactive technology both exciting and helpful in motivating student learning and attendance. We also noted some drawbacks to the use of technology, but we do not believe the problems to be insurmountable.

\section{Educational Impact}

As the opportunities for technology-enhanced education grow, assessing the real educational value of new advancements is particularly 
important. ${ }^{1}$ With support from the Ameritech Foundation (see BoxSteffensmeier 1998-99), ${ }^{2}$ we made such a preliminary assessment of one technology by comparing two classes, both taught by Box-Steffensmeier in the same quarter. The only difference between the classes was the inclusion of the interactive video speaker seminars for the experimental class. ${ }^{3}$ To assess the impact of adding interactive video technology, we focused on three principal questions.

- Would students in the experimental class display greater learning and retention than students in the control class? As we discuss below, giving students opportunities to meet and speak with policymakers allows political science instructors to target a much broader range of student learning styles than they normally would.

- Would students in the experimental class display increased political efficacy and more positive attitudes toward governmental institutions, particularly Congress? Hibbing and TheissMorse (1995) suggest that exposure to the reality of democratic institutions, coupled with the acquisition of basic knowledge about those institutions, may improve long-term attitudes toward government.

- Would students in the experimental class develop more positive attitudes toward the course and political science? In a sense, we were interested in learning whether a course that plays into a broader array of student learning styles and engages students more fully also makes them generally more positive toward their classroom experience in political science.

Students were not aware when they registered for the class that there was any difference in how the classes were structured, and both sections were offered at popular times of the day (late morning and early afternoon). The experimental class had conversations throughout the quarter with many influential

\section{TABLE 1}

\section{Percentage of Class Sections Giving "High" Responses}

\begin{tabular}{|c|c|c|c|}
\hline & $\begin{array}{l}\text { Traditional } \\
(\mathrm{N}=23)\end{array}$ & $\begin{array}{c}\text { Video } \\
(N=15)\end{array}$ & Difference \\
\hline Intellectually stimulating & 11 & 93 & $82^{*}$ \\
\hline Instructor interested in teaching & 78 & 93 & 15 \\
\hline Encouraged independent thinking & 67 & 79 & 12 \\
\hline Communicated subject matter clearly & 22 & 93 & $71^{*}$ \\
\hline Instructor interested in helping students & 44 & 86 & $42^{*}$ \\
\hline Learned greatly from instructor & 33 & 71 & 48 \\
\hline Created learning atmosphere & 22 & 86 & $64^{*}$ \\
\hline Overall Rating & 22 & 79 & $57^{\star}$ \\
\hline
\end{tabular}

Note: Students evaluated each item on a five-point Likert-type scale using the university's standard course evaluation form. Percentages are of those who gave the highest rating of five.

${ }^{*} p<.05$

and visible participants in Washington politics. We gave each videoseminar speaker only a minimal outline of what topics to address in a brief lecture to the class, and we allowed the interaction between the class and the speaker to be guided largely by the students' questions and the speaker's insights. Within this relatively open-ended format, the speakers offered ideas and illustrations that reinforced key course concepts and helped bring those concepts alive for the students.

Senator Richard Lugar (R-IN), for instance, spoke about the changes in Senate norms that he has witnessed during his twenty-plus years in Washington. In doing so, Senator Lugar illustrated for the class a key political science conceptthat informal norms have been central to the Senate's operation (Matthews [1968] 1973) and that many of those norms have decayed during the last several decades (Asher 1973; Sinclair 1989). Candy Crowley, congressional correspondent for CNN, discussed how television has changed the operation of Congress and how the media has decreased members' willingness to express a cautious uncertainty on complex issues. Al Quinlan, president of Greenberg-Quinlan Research, offered a detailed description of opinion polling and campaign strategy from the earliest stages of a congressional election campaign through election day. Each of the eight speakers fielded a number of questions on current events, but the students also asked deeper questions related to core ideas from the course.

The interactive video discussions improved the overall learning experience for students. Although the two classes covered the same material and were taught by the same instructor, students in the video class expressed dramatically more positive reactions to the course than did those in the traditional class. These differences can be seen clearly in Table 1, which displays the results of the course evaluations. While students in both classes believed the instructor to be interested in teaching and encouraging independent thinking, those in the video class found their course more intellectually stimulating and more conducive to learning. Moreover, in the eyes of the students in the video class, the instructor was better able to communicate the material clearly. Overall, the percentage of students in the experimental section ranking the instructor or the class in the highest category was nearly four times as large as the corresponding percentage in the traditional section. ${ }^{4}$

In the open-ended written evaluations, students in the video course frequently commented on how the combination of course activities were suited to various styles of 
learning. Asked "What was best about this course?" students replied:

- The speakers were fabulous, and I really enjoyed the labs. Changes in pace are wonderful for keeping my attention, and I suspect the same goes for others, too. The class is structured very nicely.

- The video conferencing was an incredible way to learn personally from a member on the Hill or a staffer.

- The interaction with those on Capitol Hill made this course one of my favorite classes.

- It wasn't simply lecture. It was a combination of lecture, labs, [and] interaction with others via satellite. All [of these] helped keep the course interesting.

While there was some division of opinion among the students over some aspects of the course (e.g., the data analysis labs), more than $70 \%$ mentioned the interactive seminars positively, and none mentioned them negatively.

Clearly, the experimental course engaged the students. It also appears to have increased the students' grasp of the theoretical material. On average, students in the video seminar received higher grades than students in the other section. Though both sections were graded on the basis of nearly identical tests and assignments, the experimental class's average grade was "B"; the traditional class's average was " $\mathrm{C}+$ ". Seventy-one percent of students in the video course responded with the highest rating for an assessment of having "learned greatly from instructor," compared with only $22 \%$ of those in the traditional class.

Although we can only engage in informed speculation on the causes of the video students' greater success, the written comments (and our discussions with the students) support the belief that undergraduates possess varied learning styles and benefit from courses that feature numerous kinds of learning opportunities. Fox and Ronkowski (1997) found that the four main learning styles, as outlined by Kolb (1984),

TABLE 2

Changes in Attitudes and Knowledge

\begin{tabular}{lccc}
\hline & $\begin{array}{c}\text { Traditional } \\
(\mathrm{N}=10)\end{array}$ & $\begin{array}{c}\text { Video } \\
(\mathrm{N}=17)\end{array}$ & Difference \\
\hline Change in Political Science Attitudes & 0.20 & -0.11 & $0.31^{*}$ \\
Change in Attitudes toward Politics and & 0.19 & -0.10 & 0.29 \\
$\quad$ Government & & & \\
Change in Attitudes toward Congress & 0.15 & 0.07 & 0.08 \\
Change in Recognition of Political Leaders & $-0.60^{*}$ & $-0.55^{*}$ & 0.05 \\
Change in Knowledge of Congress & $0.19^{*}$ & $0.24^{*}$ & 0.05 \\
Change in Knowledge of Own Member & $0.36^{*}$ & $0.38^{*}$ & 0.02 \\
\hline Note: Cell entries reflect the changes in students' overall responses to a series \\
of questions from each category. See Appendix for a list of the questions that \\
are combined in each category. \\
* $p .05$.
\end{tabular}

are well distributed among undergraduates taking political science courses, and they recommend that political science instructors employ more diverse approaches to target all styles. Brock and Cameron (1999) also suggested that political science education is biased toward certain learning styles and argued even more forcefully than Fox and Ronkowski that each learning style needs to be accommodated. We believe that the positive course evaluations and heightened academic performance among the experimental class' students suggest that our approach may be tapping the breadth of styles that these scholars analyze.

As an alternative instructional method, interactive conferencing improved the learning experience of students and their grasp of the theoretical materials, but we were also interested in its effect on their assessment of politics and political science. We expected that introducing students to public policy leaders through interactive technology would help them develop greater efficacy and increase their participation in politics. We also believed it might engender in them more positive attitudes toward political science and politics. Indeed, Hibbing and Theiss-Morse have suggested that simply gathering information about politics, and about Congress in particular, does little to improve citizens' attitudes about government. Rather, realistic exposure to and education in the working of democratic institutions does much more to improve attitudes in the long run. According to Hibbing and TheissMorse, Americans lack an appreciation for the "ugliness of democracy," the inherent raucousness and necessity of compromise that pervades democratic institutions, and legislatures in particular $(1995,157)$. We expected, therefore, that extended discussions with people involved in democratic processes would increase students' efficacy and make their attitudes toward Congress more positive.

To test these expectations, we surveyed students before and after the course. The surveys included questions on students' attitudes toward political science, politics and government, and Congress (see Appendix). Other survey items measured knowledge of political leaders, of Congress, and of each student's own member of Congress. For each set of items, we created a scale for the pretest and post-test. Table 2 presents the average differences between these two scales for each class. An increase indicates that students in a class became more positive or more knowledgeable, while a decrease indicates that students' attitudes became more negative or that students became less knowledgeable. For each item, we calculated whether the change was statistically significant $(p<.05)$ and then whether the average change was statistically significant.

We found no evidence that the students who interacted with policymakers became more positive in 


\section{Appendix \\ Pre- and Post-test for Attitude and Knowledge Changes}

Political Science (positive scores are high)

1. I enjoy political science.

2. I would be willing to attend an unassigned lecture by a political scientist.

3. I enjoy reading articles about political science topics.

4. I use political science concepts to analyze current events.

5. On occasion, I read an unassigned book in political science.

6. Political science is more opinion than facts.

7. Political science is easy for me to understand.

8. Political science is one of my favorite subjects.

9. Political science is practical.

10. Political science is dull.

11. Political science is a very difficult subject for me.

12. Political science is one of my most dreaded subjects.

14. Studying political science is a waste of time.

American Politics and Government (positive scores are high)

20. I don't think public officials care what people like me think.

21. People like me don't have a say in what the government does.

22. Sometimes politics and government seem so complicated that a person like me really can't know what's going on.

23. I can trust the government in Washington to do what is right.

24. Government is run by a few big interests.

25. Government is run for the benefit of all the people.

26. Almost all of the people in government are crooked.

Congress (positive scores are high)

27. Congress does a good job representing the diverse interests of Americans, whether black or white, rich or poor

28. Congress addresses difficult issues in a reasonably efficient way.

29. Congress is too far removed from ordinary people.

30. There are too many staffers or assistants in Congress.

31. Just a few members of Congress have all of the power.

32. Members of Congress focus to much on events in Washington.

33. Members of Congress are too sensitive to what the public opinion polls tell them their constituents want.

34. Congress and the bureaucracy work together in making good public policy

35. Members of Congress only core about getting reelected, not about making good policy.

Recognition of Political Leaders $\{1=$ identifies person $\}$

1. Al Gore

2. William Rehnquist

3. Dennis Hastert

4. Trent Lott

5. Tom Daschle

6. Dick Gephard

Knowledge of Congress and our other bronches of government. (1 = right answer)

7. Who has the final responsibility to decide if a law is constitutional or not. is it the president, the Congress, or the Supreme Court?

8. Whose responsibility is it to nominate judges to the federal courts. Is it the president, the Congress, or the Supreme Court?

9. Which party has the most members in the House of Representatives?

10. Which party has the most members in the Senate?

11. Which House committee proposes procedural rules for debate?

12. What proportion of senators are needed to stop a filibuster?

13. What proportion of senators are needed to pass a bill?

14. What proportion of House votes are needed to pass legislation brought up under suspension of the rules?

16. What proportion of votes are needed to override a presidential veto?

17. How many years are in a senator's term?

18. How many years are in a House representative's term?

19. Which chamber-House or Senate-ratifies treaties?

20. Sometimes the House and Senate pass legisiation that has different language. What is the name of the commiltee responsible for reaching compromises between these different versions of legislation?

21. How many members does the House of Representatives have?

22. How many members does the Senate have?

Knowledge of their own members (1 = right answer)

23. What are the names of your U.S. senators?

24. What is the name of your representative to the House of Representatives?

25. Is your House representative a Republican or Democrat?

26. What is the race or ethnicity of your representative?

27. Is your House representative a male or female?

Note: Questions for the pre- and post-course surveys were adapted from Agarwal and Day (1998), Hibbing and Theiss-Morse (1995), and various years of the American National Election Study. their attitudes toward political science, politics and government, or Congress. In fact, the only set of items that shows any statistically significant difference between the two classes is the change in attitudes toward political science. Students in the traditional class became more positive toward political science ( $p$ $=.10$ ), while those in the video class did not change their views significantly. ${ }^{5}$ Both classes became significantly more knowledgeable about Congress and their own members, and the change was similar for both classes. Curiously, the students became less knowledgeable about particular political leaders, perhaps because they were deluged with the names of so many past and current leaders over the quarter. Increasing students' current events knowledge was not an objective of the class, though, in retrospect, it probably should have been.

In summary, interaction with politicians improves the learning experience by increasing students' engagement and their grasp of factual and conceptual material. We found no evidence, however, that the interaction improves student attitudes toward politics or Congress. ${ }^{6}$ However, we believe it is possible that students are reacting to their initial exposure to the reality of politics-a reaction that we noted frequently in our informal discussions with the students. If students choose to act on the basis of this reaction, their participation in politics may increase over time because they know realistically what to expect and have definite ideas about how they would like to see the political system changed.

\section{Assessment and Recommendation}

Educators and university administrators around the country are exploring the advantages and disadvantages of offering technologyenhanced classes. As costs drop and classroom technologies become more available, the use of educational tools such as interactive video will become more common. Our project provides systematic evidence to evaluate the impact of technologi- 
cal advances that make interaction with policymakers possible.

As the written and quantitative course evaluations reflect, this type of course is enjoyable and engaging for the students and the instructor. Unlike most of their other classes, the video class allowed students to bridge the divide between the theories presented in the classroom and the real world of politics. The interactive course also improved learning by students with varied learning styles, increased student engagement and performance in the course, and allowed the scheduling of speakers of higher quality and greater relevance than are typically available. The addition of the interactive video speakers was low-cost for students and provided them with a high level of benefit. Some students, for instance, even made job inquiries and have continued to keep in contact with the speakers since the course ended.

For the instructor, the major cost was her time, since the course required extensive planning and coordination with the speakers and technology staffers at Ohio State and at the remote sites. Fortunately, the direct cost of staging the seminars (approximately $\$ 400 /$ hour for each speaker) was kept low thanks to the cooperation of the staff at George Washington University, who provided their services at a significantly reduced rate compared with commercial facilities in Washington, DC. And, even lower-cost options are available. Representatives and Senators can use the House and Senate galleries for free. Also, instructors at more than one university can collaborate to allow their students to converse with a speaker at a common time, pooling resources to minimize costs. For smaller universities, such collaboration may make video conferencing more feasible while costs remain relatively high. In our experiment, this type of linkage proved quite successful. Some speakers scheduled for our class at Ohio State connected simultaneously with a subset of students taking a course taught by Patrick Sellers at Indiana University.

As instructors, we benefitted from the opportunity to see students become excited about politics when speakers such as Anna Cabral, staff director for the Senate Judiciary Committee, talked about how her humble beginnings and strong desire to help others led her to pursue a phenomenal political career. We also had the opportunity to discuss current research interests with the speakers. Additionally, the tapes of the speakers will be useful for many years to come. We have used some of our tapes, for instance, in a subsequent course by making them available on the Internet through streaming video (Anderson and BoxSteffensmeier 1999). ${ }^{7}$ The initial financial cost seems more reasonable when this long-term benefit is considered.

Finally, it is important to emphasize that the interactive nature of the course appears to have yielded unique benefits. A comparison between our course experiment and a similar earlier experiment with technology (see Jordan and Sanchez 1994) highlights this key distinction. Jordan and Sanchez used noninteractive video clips to highlight course concepts in one American politics course and compared the performance of students in that course to students in an otherwise-identical nonvideo class. They found little significant difference in student learning as a result of their use of the noninteractive video technology. In light of their findings, we can assert with greater confidence that the interactive video technology we used in our course improved student learning by providing an opportunity for real interaction between students and policymakers, fostering active rather than passive learning. Because interactive seminars engage various student learning styles and enhance the overall class experience, we believe that instructors should consider their use in a variety of undergraduate political science courses.

\section{Notes}

1. The overwhelming conclusion of the numerous studies on the use of instructional technology is that it increases effectiveness of instruction, although most of these studies are descriptive and do not provide statistical evidence (Agarwal and Day 1998, 100; Bailey and Cotlar 1994; Kearsley, Lynch, and Wizer 1995; Zack 1995).

2. The lead author performed the preliminary assessment as an Ameritech Faculty Fellow. The authors thank Ameritech for its support.

3. The design followed that of Agarwal and Day (1998).

4. We note that, since the two courses were taught by the same professor, we are able to assert more directly that use of the technology enhanced the student experience. However, the comparison between the two classes also depends on how well students receive this specific course and professor. In other words, if students consistently disdain a particular professor, or if all students rate a particular course highly, then we would of course not expect to find any significant effect from adding a new aspect to the course.

5. Although it is troubling that the video class became somewhat more negative about political science, the finding is not particularly surprising. Most likely, the video course may have highlighted "real politics" to such an extent that students viewed textbook political science knowledge more critically. But, since our survey measures do not probe the reasons for these changes, we can only speculate on this phenomenon.

6 . This finding may be the result of individuals projecting commonly held expectations of the market economy onto their expectations of politics, as Gangl (1999) has argued. Gangl critiqued Hibbing and Theiss-Morse (1995) on the basis that Americans' skepti- cism of the legitimacy of the legislative process relates to citizens' expectation that features of the American economic system will be reffected in politics. In Gangl's theory, people increasingly expect from the legislative process the same degree of efficiency, accountability, and equality of opportunity that they perceive the market to offer, even though mechanisms of democratic government cannot match these economic expectations.

7. Anderson and Box-Steffensmeier thank the Dirksen Congressional Center for supporting this later project through the Robert Michel Civic Education Grant Program, and Box-Steffensmeier thanks the Technology Enhanced Learning and Research Program at Ohio State University. The streaming video versions of the lectures used in this later course are available at http://psweb.sbs.ohiostate.edu/faculty/jbox/ps367realvideo.htm. 


\section{References}

Agarwal, Rajshree, and A. Edward Day. 1998. "The Impact of the Internet on Economic Education." The Journal of Economic Education 29:99-110.

Anderson, William D., and Janet M. BoxSteffensmeier. 1999. "The Legislatures and Interest Groups Project." Pekin, IL: Robert Michel Civic Education Grant Program, Dirksen Congressional Center.

Asher, Herbert B. 1973. "The Learning of Legislative Norms." American Political Science Review 67:499-513.

Bailey, E.K., and M. Cotlar. 1994. "Teaching Via the Internet." Communication Education 43:184-93.

Box-Steffensmeier, Janet M. 1998-1999. "Impact of Interactive Video Seminars: The Classroom on Capitol Hill Project."

Brock, Kathy L., and Beverly J. Cameron. 1999. "Enlivening Political Science Courses with Kolb's Learning Preference
Model." PS: Political Science and Politics 32(June): 251-56.

Crawford, Sue E.S. 1998. "Internet Lite: Short Internet Assignments for American Government Courses." PS: Political Science and Politics 31(September): 573-77.

Fox, Richard L., and Shirley A. Ronkowski. 1997. "Learning Styles of Political Science Students." PS: Political Science and Politics 30(December): 732-36.

Frantzich, Stephen. 1995. Congressional Database Analysis Package. 2nd ed. Washington, DC: National Planning and Consulting Corporation.

Gangl, Amy. 1999. "The Impact of Expectations of Legislative Processes on Legitimacy Perceptions." Ph.D. diss. proposal, University of Minnesota.

Hibbing, John R., and Elizabeth TheissMorse. 1995. Congress as Public Enemy: Public Attitudes Toward American Political
Institutions. Cambridge: Cambridge University Press.

Jordan, Donald L., and Peter M. Sanchez. 1994. "Traditional versus TechnologyAided Instruction: The Effects of Visual Stimulus in the Classroom." PS: Political Science and Politics 27(March): 64-67.

Kearsley, G., W. Lynch, and D. Wizer. 1995. "The Effectiveness and Impact of Online Learning in Graduate Education." Educational Technology 35:37-42.

Kolb, D.A. 1985. Learning Style Inventory. Boston: McBer and Co.

Matthews, Donald R. [1968] 1973. U.S. Senators and Their World. Chapel Hill: University of North Carolina Press.

Sinclair, Barbara. 1989. The Transformation of the U.S. Senate. Baltimore: Johns Hopkins University Press.

Zack, M. 1995. "Using Electronic Messaging to Improve the Quality of Instruction." Journal of Education for Business 70(March/April): 202-06. 